「カワヒバリガイ問題」の始まりと現在の課題

中井克樹

滋賀県立琵琶湖博物館７525-0001 滋賀県草津市下物町 1091

\title{
Problems of the golden mussel (freshwater mytilid): Emergence and future perspectives in Japan
}

\section{Katsuki Nakai}

Lake Biwa Museum, Shiga Prefecture, Oroshimo-cho 1091, Kusatsu, Shiga 525-0001, Japan

(Accepted February 9, 2010)

キーワード : カワヒバリガイ、琵琶湖・淀川水系、木曽川水系、分布拡大リスク評価、着底トラップ、流下ゴミ

はじめに

カワヒバリガイ属Limnopernaは、東アジアから東南 アジアにかけての淡水域に生息するイガイ科二枚貝で複 数種を含むことが知られており、2005年 6 月に外来生物 法が施行された際、その規定する「特定外来生物」に属 単位で指定され、厳しい規制の対象となっている。現在 のところ、カワヒバリガイ属のなかで日本国内に侵入 ・ 定着した種は、カワヒバリガイLimnoperna fortuneiの みである。

カワヒバリガイの日本国内への侵入が最初に気づかれ たのは1992年 2 月、滋賀県琵琶湖の湖岸で 1 個体が採取 された時であった。その後、同年の秋までに、琵琶湖で の発見が偶然のものではなく、すでに本種は湖内に定着 していることが確認された。これに先んじて、韓国・ソ ウル近郊の漢江の八堂ダムにおいて、この貝が大発生し 問題となっていることが国内で報告されていたため、琵 琶湖でも同様の被害が生じるのではないかと䀣念された。 さらに、1980年代後半に、北アメリカ五大湖においてヨー ロッパから侵入したカワホトトギスガイ (ゼブラガイ) Dreissena polymorphaが激増し、その影響は、五大湖 という世界最大規模の淡水生態系を大きく変容させ、利 水施設の運用にも深刻な打撃を与えるという、激甚なも のであることが知られるようになってきていた。このカ ワホトトギスガイとカワヒバリガイとは分類的位置が大 きく異なるが、淡水生貝類としては例外的に「生活史の 初期にプランクトンとして生活する浮遊期を持つこと」、 および「貝として着底後に足糸を分泌して固い基盤に固 着した生活を送ること」という生態的特徴を共通して持
ち、これらの特徴が、まさしく生態系への悪影響や利水 施設での被害に関係する。そのため、琵琶湖においてカ ワヒバリガイが、五大湖でのカワホトトギスガイのよう な著しい被害をもたらすのではないかとの不安がかき立 てられた。さらに、琵琶湖に次いで、木曽川水系へもカ ワヒバリガイが侵入していることが確認され、琵琶湖・ 淀川水系とともに、来るべき「カワヒバリガイ問題」に 対処す心゙く、河川管理者や利水関係者による調査も進め られた。

しかし、琵琶湖・淀川水系および木曾川水系では、一 部の利水施設に大規模に侵入し、それへの対策がとられ たが、深刻な被害が拡大・継続するまでにはいたらなかっ た。また、新たな生息確認水域が見つかることもなく、 いつしか「カワヒバリガイ問題」への関心そのものが薄 らいでいった。ところが、2000年代に入って、愛知県矢 作川、静岡県天竜川、そして群馬県鏑川、茨城県利根川・ 霞ヶ浦において、カワヒバリガイの侵入がたてつづけに 確認されたことで危機感が再燃し、農林水産省が対策事 業を始めるなど、「カワヒバリガイ問題」への対策が本 格的に検討されるようになってきた。

ここでは、日本における「カワヒバリガイ問題」の歴 史の早期にあたる琵琶湖・淀川水系および木曾川水系 （以下、「早期侵入水域」という）での生息確認の歴史を 振り返るとともに、その後、2000年代に入って新たに確 認された生息水域（「後期侵入水域」という）での状況 を踏まえて、今後の課題について述べてみたい。 


\section{1.「問題」の始まり：早期侵入水域における生息域拡大 (1) 琵琶湖 · 淀川水系}

カワヒバリガイの最初の個体は、1992年 2 月に琵琶湖 の北湖南東部に位置する近江八幡市の湖岸で発見された。 この時に採集されたのは 1 個体のみで、定着には至らな い偶産的なものである可能性も捨て切れなかった。しか し、同年 8 月に第一発見場所とは少し離れた別の地点で 複数の個体が発見されたことを受け、同年の秋に湖岸全 域を対象に生息調査が実施された。その結果、カワヒバ リガイの生息は、琵琶湖の南東部湖岸、すなわち北湖南 東部（近江八幡市）から南湖東岸（守山市、草津市、大 津市）にかけて、および流出河川である淀川（滋賀県内 では瀬田川と呼ばれる）の瀬田川洗堰の直下で確認され、 そのサイズ分布はすでに湖内で繁殖・定着していること を示唆するものであった。

その後、1994年から1996年にかけて建設省、水資源公 団、滋賀県の 3 者が合同で実施した大規模調査により、 下流方向には流出河川である淀川（瀬田川・宇治川）の 淀川大堰までの淡水域全域に、カワヒバリガイが生息範 囲を拡大していることが明らかになった。また筆者らに よる同時期の調査結果を合わせると、湖内での分布範囲 は、北湖では分布の北端が彦根市まで伸び、南湖では西 岸に及んだ。その後、1990年代末までに、生息が未確認 のまま残された北湖の北岸から西岸にかけての地域にお いても、ベントス調査や定置網等の漁具の点検の際など に発見されるようになった。現在では、琵琶湖の全域の 湖岸に生息しているとみてよい状況にある。

琵琶湖・淀川水系におけるカワヒバリガイの分布拡大 の様相は、上流側の止水域の琵琶湖に侵入した後、下流 側へは流出河川の水の流れ下る方向へと速やかに分布範 囲を広げ、また止水域である広大な湖内では湖流の影響 で徐々に湖岸伝いに広がって湖全域の分布が達成された と推測される。こうした分布拡大のパターンは、本種が 水の流れに乗って生息域を拡大した結果であることを示 唆するものである。これは、カワヒバリガイが生活史初 期の浮遊期に水の流れを利用した大きな分散能力を持つ、 とのリスク予測を裏付けるものである。

\section{（2）木曽川水系（木曽三川）}

カワヒバリガイが琵琶湖で発見された翌1993年には、 河口堰の建設問題に摇れていた長良川から潜水調査によっ て採取されたイガイ科二枚貝が筆者のもとに届けられ、 それがカワヒバリガイであることが判明した。採集者は、 河口堰建設に伴う河道改変により汽水域が拡大したこと により、汽水生の外来種コウロエンカワヒバリガイが生 息範囲を上流へと拡大している証拠になるのではないか との期待をもっていたのだが、そうではなく琵琶湖に続 く、カワヒバリガイの第二の生息水域の発見となったわ けだ。その後の調查により、長良川から取水する農業用 水の揚水機場にも大規模に侵入していることや、長良川 と平行して流れる揖斐川と木曽川の下流域に広範囲に生 息していることも明らかとなった。そして、既存の標本 資料を再検討した結果、1988年に揖斐川で採取された標
本がカワヒバリガイと同定され、これが国内で最も古い 本種の確認記録となった。

木曾三川（木曾川、長良川、揖斐川）、寸なわち木兽 川水系では、最も早期に標本個体が採集されてから侵入 に気づくまで 5 年が経過していたことから、分布調査の 実施時には、すでに侵入後かなりの時期を経ていたもの と推測される。長良川と揖斐川では、カワヒバリガイは 河口部周辺には生息せず、生息範囲の上流端は感潮域の 上限とほぼ一致していた。一方、木曽川での生息範囲は、 河口域を除く木曽川大堰の下流側の一部に限られていた。

長良川河口堰がまだ操業されていない時点では、周辺 の川岸の石組みだけでなく、河口堰ピアにもカワヒバリ ガイが付着していた。ピアにおける付着位置は水面直下 に限られ、それより下部には主に汽水域から内湾に生息 するコウロエンカワヒバリガイが付着していた。また、 確認されたカワヒバリガイは、すべて当歳個体と推測さ れる小型のものばかりであった。この鉛直分布のパター ンと、河口部周辺ではまったく確認されない水平分布の パターンからは、カワヒバリガイは塩分耐性がかなり低 いことが示唆される。

また、生息範囲の上流端が河川の感潮域の上端にほぼ 一致したことは、受精卵と幼生時期に浮遊生活を送る力 ワヒバリガイの生息域が、潮汐によって河川水が移動す る範囲内で維持されていることを示すものだと考えられ る。

\section{2. 分布拡大のパターン}

\section{（1）水系内における分布域の確立}

早期侵入水域である琵琶湖・淀川水系と木曾川水系に おけるカワヒバリガイの分布域の確立過程は、「生活史 の初期に浮遊期を持つ」という本種の生態的特徵から予 測される結果と整合するものであつた。すなわち、水の 流動によって着底間近な幼生が運ばれる範囲に本種の生 息域が拡大寸る、ということである。

同様の「当然」の予測は、これら 2 水系に次いで発見 された愛知県の矢作川水系でも別のパターンとして検証 されることになった。矢作川では、上流域に位置する矢 作第一ダムの直下が最上流の確認地点であったことから、 少なくともその直上の矢作第一ダム貯水池にも生息する ことと、そこから河川水が流下寸る河口域にいたるまで の範囲に分布域が確立されると予想された。そして、そ の後の調査により、矢作川での生息範囲がこの予想に合 致していることが確かめられた。

一定期間の浮遊期を持つカワヒバリガイが、河川とい う水が恒常的に下流方向に流れる流水環境において安定 した個体群を持続できる範囲は、感潮域のように潮汐の 影響で河川水が自然に上流・下流へと移動する流程区間 を除けば、ダム貯水池のような一定規模の止水環境の存 在が不可欠で、生息範囲の上流端はそうした止水環境で あることが予測される。

そして、矢作川と同様の分布パターンは、矢作川から 県境を隔てた静岡県の天竜川水系でも、佐久間ダム貯水 池と新豊根ダム貯水池を上流端とする生息範囲が確立さ 
れることで、示されている。なお、天竜川・佐久間ダム の水は、佐久間導水路によって県境を越えて愛知県側の 豊川水系・宇連川へと供給され、そこから下流側の豊川 水系へのカワヒバリガイの侵入をもたらし、豊川を水源 とする豊川用水では農業施設の被害が生じ始めている。

霞ヶ浦を含む利根川下流域では、茨城県を中心に生息 確認地点が霞ヶ浦より上流側にも広がっているが、上流 端としての確認地点は霞ヶ浦からの導水の供給地点であ ることから、この水系における分布様式も、水の循環様 式によって説明できるものである。

\section{（2）奇妙な分布が示唆するもの}

日本国内におけるカワヒバリガイの分布様式のなかで 奇妙なのは、群馬県を流れる利根川水系の支流、鏑川流 域におけるパターンであろう。この水系では、最初に生 息が確認された大塩貯水池が生息確認地点の上流端で、 そこから導水される鏑川用水への侵入が問題視されてい るが、農業用水が流入して再度蓄えられる竹沼貯水池よ りも下流側では、生息密度が著しく低く、農業用水が最 終的に合流寸る鏑川本川や、さらに鏑川の合流点よりも 下流側の利根川の中流域では、生息が確認されていない。 なお、カワヒバリガイは霞ヶ浦を含む利根川下流域でも 生息域を拡大しているが、それは鏑川水系のものとは遺 伝的特徵が大きく異なり、本種の利根川下流域への侵入 は上流の鏑川由来ではないことがほぼ確実である。

このように、鏑川流域のカワヒバリガイは、現在のと ころ、生息範囲が下流方向にほとんど広がっていない点 で、これまで知られている貯水池を上流端とする河川に おける分布パターンと大きく異なっている。鏑川水域に おいてカワヒバリガイの生息域が下流方向へ拡大しない のは、単に時間的・確率的な問題であって時間が経てば 広がっていくのか、あるいは、何か特別な原因があって 分布域の拡大が制限されているのかについて、注意深く 見守っていく必要がある。同様にダム貯水池で局所的に 分布が確認されているパターンとして、淀川支流の木津 川上流の高山ダム貯水池（京都府・奈良県）の例がある。

\section{3. 今後の課題}

\section{（1）侵入経路の解明}

カワヒバリガイは、現在のところ、琵琶湖・淀川、木 津川、木曽三川、矢作川、天竜川、鏑川、利根川・霞ヶ 浦において、侵入・定着している。これらの水域への侵 入が、海外から輸入されたものが直接に持ち込まれたこ とによるのか、あるいは国内にすでに定着した水域から 国内移動によって別の水域へと拡大したことによるのか、 現在のところよくわかっていない。これまでの経緯を振 り返ると、輸入個体の直接の持ち込みだけでなく、すで に定着した水域から国内移動によって別の水域へと広がっ た可能性もありうる。また、遺伝的分析によれば、利根 川・霞ヶ浦以外の集団は遺伝的特徵が類似しており、後 期侵入水域へは初期侵入水域に定着したカワヒバリガイ がもたらされたと考えても、確かに矛盾はしない。しか し、その一方で、早期侵入水域にカワヒバリガイを持ち
込んだのと同様の行為が、後期侵入水域では行われなかっ たと断ずることはできず、むしろ、その蓋然性は十分に 高いと想定すべきであろう。

まず、カワヒバリガイが原産地からもたらされた経路 として現在、東アジア諸国からの生きたシジミ類への混 入が想定されている。1980年代より増加傾向にあったシ ジミ類の輸入量は、国内におけるシジミ（主にヤマトシ ジミ）の漁獲量に匹敵する規模になっている。そして、 外国産シジミにカワヒバリガイが混入していた事例とし ては、揖斐川河口の漁協で畜養されたシジミに混じって いた例から、シジミの味噌汁の具材として出てきた例ま で、いろいろな具体例が確認されている。また、外国産 シジミは形態的に変異が大きいためにマシジミなど在来 種との分類的識別が難しいとされるなかで、最も外国産 シジミとして認識されやすい、淡い黄褐色を基調とし一 部が褐色に染め分けられた「カネッケシジミ」型のシジ ミだけでも、国内のかなりの水域で確認されるようになっ てきている。外国産シジミの野外水域での発見・確認の パターンにより、大量に輸入されたそれらが、日本国内 の多くの野外水域へと独立して持ち込まれていることが 示唆される。そして、こうした外国産シジミの持ち込み の際に、カワヒバリガイが混入している場合も、十分に ありうると予測される。

このように、日本に侵入したカワヒバリガイが外国産 シジミに混入して持ち込まれた可能性はかなり高いと思 われる。ただし、各地で外国産シジミを野外水域に放つ 行為自体が、なぜ、どのようにして行われるのかすら未 だによくわかっておらず、われわれ人間の行為について の探求も今後の課題であろう。そしてまた、定着水域を 供給源とした国内移動による分布域拡大の可能性につい ても、どのような経路がありうるのかを十分に想定して おくことは、リスク管理の観点からも重要である。

\section{（2）国内移動のリスク評価}

外来種が持ち込まれた先で定着するには、繁殖に成功 することが不可欠である。固着生活を送り体外受精する という特徽を持つカワヒバリガイが、侵入先で繁殖に成 功するには、新たに侵入した個体が此雄の成熟個体に成 長し、それらが比較的近くで固着生活を送る状況が必要 だと推測される。また、カワヒバリガイの場合には、成 長段階によって侵入をもたらす過程が異なっているため、 受精卵・幼生の成長段階では浮遊期に水に混入した侵入 を、固着期にあたる着底後の貝（幼貝〜成貝）では、個々 の個体が物資や他の生物に固着・混入した状態での侵入 を想定する必要がある。

浮遊期の微小な個体が水に混入して持ち込まれる場合 には、現場の水域の大量の水で希釈されたうえ、着底す るまでに水中を漂う期間があることを考えると、変態期 を迎えた幼生が持ち込まれた先で成熟後に繁殖可能な程 度に近接して着底できる可能性はきわめて低いと考えら れる。したがって、カワヒバリガイの生息水域の水を移 動させる経路として、魚類種苗等の種苗放流が指摘され るが、放流に伴う運搬用の水の量が限定的であることも 
考慮すると、少なくとも放流先が流水環境である場合に は、放流種苗に混入して浮遊期のカワヒバリガイが混入 したとしても、それに由来して個体群が定着するリスク は、かなり低いと推測される。

一方、魚類の移植放流に際しては、種苗の魚に食べら れたカワヒバリガイが、生きたまま消化管を通過して放 流先で排泄される、という固着期の貝としての侵入経路 も否定できない。放流対象となる魚種が実際にカワヒバ リガイを食べる可能性がある場合には、固着期のカワヒ バリガイが生きたまま消化管を素通りできるかどうかを 実験的に検証し、この経路のリスクの高さを評価するう えで検討する必要がある。また、固着期の貝としては、 シジミや土砂などの “散布物資”に混入して導入される 場合や、船舶や機材といった”利用物資”に付着して侵入 する場合が想定される。どちらの場合も、持ち込まれた 個体があまり移動せずに居場所を定め繁殖可能な状態に 至る可能性が高いために、定着リスクの高い経路と考え られる。カワヒバリガイの定着水域からのシジミ等の種 苗の移植や、“川砂” としての建設・工事用の土砂の搬 入は混入リスクの高い行為であるため、もし実施される とすればそのリスクを低減するための対策が不可欠であ る。また、船舶や機材を水系を越えて移動させて利用す る場合にも、カワヒバリガイの付着や混入がないか、十 分に注意する必要がある。このような導入・侵入をもた らしうる行為は、関係者が比較的限定され、かつ容易に 特定されるため、系統だった周知・啓発の体制作りが望 まれる。

\section{(3) 付着のメカニズムとその応用}

導水施設におけるカワヒバリガイの着生状況でこれま でに判明した興味深いことは、水源から用水が供給され た直後に非常に高い密度での着生が見られながら、下流 方向に行くにつれ付着個体の密度が急速に減衰するとい う現象である。この顕著な減衰傾向は、水流や照度、重 力等の外部刺激に対する、着底を間近にひかえたカワヒ バリガイ幼生の生理的・行動的特性によってもたらされ ると推測される。

幼生の着底という生活史上のイベントは、その場所に 固着する貝を増加させる結果に直接的につながるため、 この貝の大規模な固着が通水障害等の原因となることを 考えると、施設管理上はできるだけ回避することが求め られている。しかし、好適な固着場所を意図的に設置し てそこへの着底を促進することで、そこから先への流下 量を効果的に減衰し、固着被害を軽減できるとすれば、 有効な「着底トラップ」が開発できる可能性にも期待が
持てる。特に、導水施設の保圧タンクや発電施設の冷却 水など、内径の小さな管内に貝が付着することでとりわ け深刻な影響が出ると考えられるデリケートな施設では、 この種のトラップ開発は有効な手法ではないだろうか。

この種の発想は、外来魚の繁殖抑制のために人工産卵 床を利用する試みにも通じるものであり、侵略性の高い 外来生物を適切に管理しその影響を抑制するために、個 体をいかに効果的に排除できるかを探るアプローチだけ でなく、十分な管理状況下へと積極的に誘引する方法を も検討する必要があると思われる。

\section{（4）付着生物として、また流下ゴミとしての対応}

カワヒバリガイの大量発生による影響が、農業用水を はじめとする利水施設で顕在化するようになってきた。 その中でも、着底した稚貝が付着生物として成長するこ とによってもたらされる通水障害に関心が集まっていた。 これに加えて、最近では、特に用水系統の末端における 流路の閉塞が各所で問題化してきている。これは、その 場所に固着した貝が次第に成長することによるものだけ でなく、壁面から離脱した固着個体の死殼の塊が上流側 から流下してきて詰まってしまうことによるものである。 カワヒバリガイ問題は、付着生物問題だけでなく、流下 ゴミ問題でもあるのだ。

これまでのカワヒバリガイ問題の検討は、この貝の基 本的な生態的知見を求めながら、利水施設内一の浮遊幼 生の侵入とそこでの幼生の着底を防止し、固着した貝を 除去するための適切な方法やスケジュールを検討するこ とに主眼が置かれていた。しかし、ここにきて、流下ゴ ミ問題についても、その原因となる死款塊の動態や性状 について調査することが必要になってきた。たとえば、 死壳塊の発生時期や流下 ・分解のプロセスは、末端施設 の維持・管理のためにはきわめて重要な情報となるはず だ。しかし、死んでしばらく経過した後の生物の死骸塊 への対策には、純粋な生物学的・生態学的なアプローチ だけでなく、物理・化学的なプロセスの追跡も必要となっ てくる。

カワヒバリガイ問題の現場となる利水施設において、 その付着生物としての影響は、水源側に近いほど大きい と推測される一方で、その流下ゴミとしての被害は下流 側ほど顕著になるといえよう。固着個体を減らす取り組 みを実施する場合には、壁面から脱落した死凯塊が流下 することで、その下流側に新たな被害をもたらさないよ う、十分な配慮が必要である。このようにカワヒバリガ イの被害防止対策においては、対策を行う現場だけでな く、その上下流域を含めた利水施設全体に目を配ること がきわめて重要であることを忘れてはならない。 